\title{
Pemberdayaan Perempuan dalam Proses Pembuatan Black Garlic menuju Masyarakat Mandiri di Era Ekonomi Industri 4.0
}

\section{Empowering Women in the Process of Making Black Garlic Towards an Independent Society in the Industrial Economy Era 4.0}

\section{Sri Mujiarti Ulfah ${ }^{1}$ \\ Solikah Nurwati ${ }^{2}$ \\ Suprayitno ${ }^{1^{*}}$ \\ ${ }^{1}$ Department of Public Administration, Universitas Palangka Raya, Palangka Raya, Central Kalimantan, Indonesia \\ ${ }^{2}$ Department of Management, Universitas Palangka Raya, Palangka Raya, Central Kalimantan, Indonesia}

*email: suprayitno@fisip.upr.ac.id

\section{Kata Kunci}

Black Garlic

Pelatihan

Produktivitas

Keywords:

Black Garlic

Training

Productivity

Received: November 2019

Accepted: March 2020

Published: June 2020

\begin{abstract}
Abstrak
Pasar Kahayan di Palangka Raya lebih terkenal sebagai pasar obat obat herbal. Manfaat black garlic (bawang hitam) tunggal sebenarnya tidak asing, namun bagi masyarakat kota palangka raya bawang hitam tunggal masih kurang familiar. Black garlic diketahui memiliki kandungan antikanker yang lebih tinggi dibanding bawang putih biasa, serta aktivitas anti bakteri. Banyaknya khasiat yang dimiliki black garlic, memberikan ruang kepada masyarakat untuk mengkonsumsi obat herbal serta peluang cukup besar untuk menjadi usaha. Melihat adanya antusiasme yang tinggi dari peserta yang terlibat dalam kegiatan Pelatihan pembuatan Black Garlic dapat disimpulkan bahwa peserta pelatihan sangat terbantu dengan adanya pelatihan ini. Peserta mampu menyerap materi pelatihan dan langsung mempraktekkan pembuatan Black Garlic dengan Baik. Pasca kegiatan pelatihan tersebut peserta telah mampu membuat produk berupa Black Garlic yang berkualitas. Dengan adanya respond yang tinggi dari peserta dan juga produk yang dihasilkan dapat disimpulkan bahwa kegiatan pelatihan pembuatan Black Garlic berhasil dilaksanakan dengan baik. Adapun saran dari kegiatan ini adalah perlu adanya monitoring berkelanjutan terkait pembuatan Black Garlic kedepannya, perlu adanya peningkatan penyebaran sasaran pangsa pasar untuk meningkatkan penjualan produk, serta perlu adanya kerjasama lintas sektor yang lebih luas agar dapat meningkatkan produktivitas black garlic kedepannya.
\end{abstract}

\begin{abstract}
Kahayan Market in Palangka Raya is more famous as a market for herbal medicines. The benefits of single black garlic are familiar, but for the people of the city of Palangka Raya, the single black garlic is still unfamiliar. Black garlic is known to have higher anticancer content than ordinary garlic, as well as anti-bacterial activity. The many properties possessed by black garlic, provide space for people to consume herbal medicines as well as considerable opportunities to become businesses. Seeing the high enthusiasm of the participants involved in the training activities of making black garlic it can be concluded that the training participants were greatly helped by the existence of this training. Participants can absorb training material and immediately practice making black garlic well. After the training activity, the participants were able to make quality products in the form of black garlic. With the high response from the participants and also the products produced, it can be concluded that the training activities for making black garlic were successfully carried out well. The suggestion of this activity is the need for ongoing monitoring related to the manufacture of Black Garlic going forward, it is necessary to increase the spread of market share targets to increase product sales, as well as the need for broader cross-sector collaboration to increase the productivity of black garlic going forward.
\end{abstract}




\section{PENDAHULUAN}

Masalah kesejahteraan masih menjadi masalah besar di Indonesia terkhusus di kota Palangka Raya Provinsi Kalimantan Tengah. Data yang dikeluarkan pemerintah Kota Palangka Raya dari data Keluarga Penerima Manfaat (KPM) beras sejahtera untuk Kota palangka raya sebanyak 5.313 kepala keluarga. Salah satu daerah tertinggi keluarga penerima manfaat adalah Kecamatan Jekan Raya dengan jumlah penerima sebanyak 1.224 KPM (Pemerintah Kota Palangka Raya, 2019).

Salah satu komplek pemukiman yang memiliki tingkat kesejahteraan masyarakat dibawah rata rata adalah masyarakat yang tinggal di kawasan mendawai. Sehinggga hal tersebut menjadi motivasi tim pengabdian kepada masyarakat (PKM) Universitas Palangka Raya agar perlu ada upaya pemberdayaan yang dilakukan untuk masyarakat sekitar (Missesa \& Syam'ani, 2019).

Kawasan mendawai terletak di belakang pasar Kahayan, pasar Kahayan merupakan salah satu pusat perbelanjaan yang cukup banyak pengunjungnya selain pasar besar Palangka Raya. Adapun dagangan masyarakat sangat variatif, diantaranya pedagang pakaian, sembako, ikan, daging bahkan cukup banyak yang berjualan obat obat herbal khas Kalimantan. Bahkan pasar Kahayan lebih terkenal pasar obat obat herbal (Akbar, 2017).

Manfaat black garlic atau bawang hitam tunggal sebenarnya tidak asing, namun bagi masyarakat kota palangka raya bawang hitam tunggal kurang familiar. Padahal menurut beberapa penelitian, black garlic memiliki kandungan antikanker yang lebih tinggi dibanding bawang putih biasa (Handayani et al., 2018; Choi et al., 2014; Dong et al., 2014; Wang et al., 2011), serta memiliki khasiat sebagai anti bakteri (Botas et al., 2019; Jang et al., 2018; Putri \& Rahayu, 2014). Banyaknya khasiat yang dimiliki black garlic, memberikan ruang kepada masyarakat untuk mengkonsumsi obat herbal serta peluang cukup besar untuk menjadi usaha (Satyaji, 2018).

Sebelum produksi dilakukan, masyarakat harus diberikan sosialisasi terlebih dahulu akan pentingnya hidup sehat, pemanfaatan obat-obat herbal sebagai alternatif, setelah itu melakukan pendampingan kepada mitra dalam proses pembuatan dan mendesain kemasan untuk dipasarkan.

\section{METODOLOGI}

Adapun Metode Kegiatan pengabdian di bagi menjadi dua, yaitu:

1. Sosialisasi pentingngnya black garlic bagi kesehatan dan menambah pendapatan keluarga.

Dalam kegiatan tersebut, Narasumber menyampaikan betapa black garlic memiliki manfaat yang luar biasa. Black garlic memiliki dampak yang positif bagi kesehatan, Beberapa manfaat black garlic diantaranya adalah meningkatkan system imun tubuh, mengurangi resiko kanker, menurunkan darah tinggi, membantu memperbaiki system pencernaan, dan manfaat positif lainnya.

2. Praktek secara langsung membuat black garlic dari bawang tunggal.

Adapun langkah - langkah dalam membuat black garlic dari Bawang Tunggal adalah sebagai berikut:

a. Alat yang di perlukan untuk proses bawang hitam lanang (black garlic lanang) untuk sekali proses:

1) Magic com kapasitas $1,8 \mathrm{~L}$

2) Aluminium foil (kertas) 1-Rol

3) Tisu makanan 3 pack

4) Kain Flanel panjang $1 / 4$ meter

5) Tiga wadah plastik

6) Bawang Putih Tunggal (lanang) $2 \mathrm{Kg}$

b. Setelah alat dipersiapkan ibu-ibu bisa melanjutkan untuk menyiapkan bahan bawang 
puth lanang (bawang puth tunggal) yang di perlukan sekali proses untuk 1 Magic Com kapasitas 1,8 L , membutuhkan sebanyak $2 \mathrm{~kg}$ bawang tunggal.

c. Proses untuk menjadi bawang hitam tunggal (blackgarlic lanang tunggal) membutuhkan waktu selama 14 hari, proses ini dinamakan fermentasi terhadap bawang putih tunggal untuk menjadi bawang hitam tunggal. Proses selama 14 hari itu untuk mendapatkan proses fermentasi yang merata maka dari hari pertama proses dinyalakan magic com-nya tanpa di proses cook, hanya dinyalakan magic comnya saja dan selama proses listrik tidak boleh dimatikan karena sampai terjadi listrik mati maka proses fermentasinya terganggu.

d. Proses yang harus dilakukan pada hari ke-7 adalah proses pembalikan terhadap bawang putih lanang yang sudah di proses selama 7 hari, supaya hasil fermentasinya merata yaitu dengan cara yang tadinya posisi bawang putih lanangnya dibawah harus ditaruh posisinya ke atas dan seterusnya.

e. Setelah pembalikan pertama pada hari ke-7, proses diteruskan dan tidak boleh listrik sampai mati atau magic com dibuka-buka hal ini supaya hasilnya maksimal.

f. Setelah hari ke-14 magic com boleh dibuka karena proses frementasi telah selesai, hasil bawang putih lanang harus benar-benar hitam proses selanjutnya segera dipindahkan ke wadah anjang (baskom) yang telah ibu-ibu persiapkan.

g. Proses selanjutnya bawang hitam lanang tadi harus ditaruh di wadah baskom dan tidak boleh ditutup, harus posisinya terbuka dengan melapisi bawah baskom menggunakan anjang supaya tidak lembab, proses ini membutuhkan waktu minimal 3 jam.

h. Setelah 3 jam bawang hitam lanang bisa dikemas dalam botol-botol dan dilakukan pelabelan atau diberi merek, yang disetai dengan bagaimana cara mengonsumsi serta uraian manfaat apa yang diperoleh dengan mengonsumsi herbal bawang hitam lanang ini.

i. Proses yang selanjutnya ibu-ibu pasarkan produk ini kepada teman/saudara/kenalan atau ibu-ibu bisa memasarkan melalui sosial media maupun media lainnya.

\section{HASIL DAN PEMBAHASAN}

Pemberdayaan masyarakat untuk meningkatkan taraf hidup dan juga kesejahteraan dalam jangka Panjang merupakan tanggung jawab semua pihak. Pemerintah telah melakukan berbagai macam upaya untuk meningkatkan taraf hidup masyarakatnya melalui program-program unggulan. Meskipun sudah ada program dari pemerintah, tetapi pada kenyataannya tidak semua masyarakat bisa menikmati program yang dicanangkan oleh Pemerintah tersebut (Rahmiyati et al., 2015). Perguruan tinggi, sebagai salah satu komponen di negara ini yang memiliki SDM luar biasa tentu tidak berdiam diri melihat berbagai masalah di masyarakat. Maka ketika Universitas Palangka Raya melaksanakan program pengabdian kepada masyarakat berupa Pemberdayaan Perempuan Dalam Proses Pembuatan Black Garlic Menuju Masyarakat Mandiri di Ekonomi Industri 4.0 adalah sebagai salah satu kegiatan pemerataan pengentasan keterbatasan ekonomi bagi masyarakat ekonomi lemah.

Keluarahan Mendawai, sebagai salah satu kelurahan yang ada di Kota Palangka Raya masih memiliki keterbatasan dalam pengembangan ekonomi kreatif. Dengan adanya program pelatihan Pembuatan Black 
Garlic Menuju Masyarakat Mandiri di Ekonomi Industri 4.0 mampu menjadi salah satu solusi untuk meningkatkan pendapatan keluarga. Selain meningkatkan ekonomi keluarga, melihat begitu besarnya manfaat black garlic bagi kesehatan tentu bisa menjadi potensi besar untuk bisa dikonsumsi oleh internal keluarganya.

Kondisi mitra adalah keterbatasan informasi pemanfaatan black garlic, tidak mengetahui dan memahami bagaimana proses pembuatan bawang putih tunggal menjadi bawang hitam tunggal serta tidak memiliki dana untuk membuatnya. Dengan adanya pelatihan ini diharapkan ibu-ibu di Kelurahan Mendawai bisa meningkatkan pendapatan keluarga tanpa mengganggu aktivitas utama sebagai ibu rumah tangga (Nelwida et al., 2019).

Kegiatan pelatihan telah dilaksanakan dengan baik. Produk Black Garlic telah dihasilkan, dimana dari $2 \mathrm{Kg}$ bawang lanang mampu dihasilkan 12-13 Botol. Adapun per botolnya kemudian dijual dengan harga berkisar antara Rp. 60.000,- hingga Rp. 75.000,-.

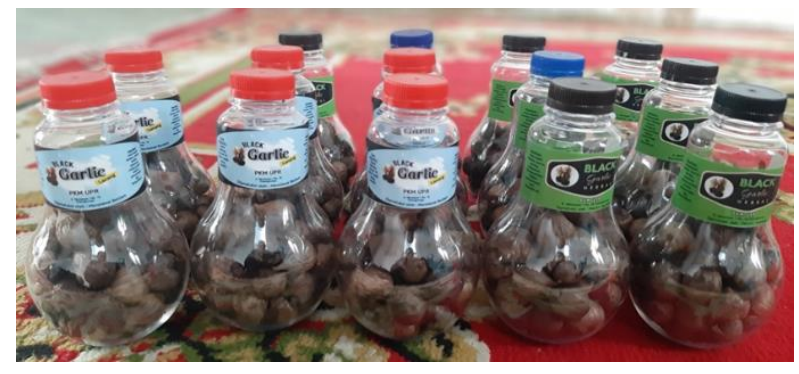

Gambar 1. Hasil Produk black garlic setelah pelatihan

\section{KESIMPULAN}

Melihat adanya antusiasme yang tinggi dari peserta yang terlibat dalam kegiatan Pelatihan pembuatan black garlic dapat disimpulkan bahwa peserta pelatihan sangat terbantu dengan adanya pelatihan ini. Peserta mampu menyerap materi pelatihan dan langsung mempraktekkan pembuatan black garlic dengan Baik. Pasca kegiatan pelatihan tersebut peserta telah mampu membuat produk berupa black garlic yang berkualitas. Dengan adanya respond yang tinggi dari peserta dan juga produk yang dihasilkan dapat disimpulkan bahwa kegiatan pelatihan pembuatan black garlic berhasil dilaksanakan dengan baik.

\section{REFERENSI}

Akbar, H. 2017. Peran Pedagang Kaki Lima (PKL) di Kota Palangka Raya dalam Memenuhi Ekonomi Masyarakat menurut Perspektif Ekonomi Islam. Skripsi. Palangka Raya: Institut Agama Islam Negeri Palangka Raya.

Botas, J., Fernandes, A., Barros, L., Alves, M.J., Carvalho, A.M., Ferreira, I.C.F.R. 2019. A Comparative Study of Black and White Allium sativum L.: Nutritional Composition and Bioactive Properties. Molecules. 24(11):2194. https://dx.doi.org/10.3390/molecules241121 94

Choi, I.S., Cha, H.S., Lee, Y.S. 2014. Physicochemical and Antioxidant Properties of Black Garlic. Molecules. 19(10):16811-16823. https://doi.org/10.3390/molecules191016811

Dong, M., Yang, G., Liu, H., Liu, X., Lin, X., Sun, D., Wang, Y. 2014. Aged black garlic extract inhibits HT29 colon cancer cell growth via the PI3K/Akt signaling pathway. Biomedical Reports. 2(2):250-254. https://dx.doi.org/10.3892/br.2014.226

Handayani, S.N., Bawono, L.C., Ayu, D.P., Pratiwi, H.N. 2018. Isolation of Black Garlic Polyphenol Compounds and Toxicity Tests on Shrimp Larvae (Artemia salina Leach). Jurnal Ilmu Kefarmasian Indonesia. 16(2):145-149. https://doi.org/10.35814/jifi.v16i2.561

Jang, H.J., Lee, H.J., Yoon, D.K., Ji, D.S., Kim, J.H., Lee, C.H. 2018. Antioxidant and antimicrobial activities of fresh garlic and aged garlic byproducts extracted with different solvents. Food Science and Biotechnology. 27(1):219-225. https://dx.doi.org/10.1007/s10068-017-02464

Missesa, Syam'ani. 2019. Pengalaman Keluarga Merawat Lansia Demensia di Wilayah Kerja Puskesmas Menteng. Jurnal Forum Kesehatan: Media Publikasi Kesehatan Ilmiah. 9(1):31-40. 
Nelwida, Berliana, Nurhayati. 2019. Kandungan Nutrisi Black garlic Hasil Pemanasan dengan Waktu Berbeda. Jurnal Ilmiah Ilmu-ilmu Peternakan. 22(1):53-64.

https://doi.org/10.22437/jiiip.v22i1.6471

Pemerintah Kota Palangka Raya. 2019. Kesejahteraan PMKS Lansia menjadi Perhatian Pemerintah Kota Palangka Raya. https://mediacenter.palangkaraya.go.id/kes ejahteraan-pmks-lansia-menjadi-perhatianpemerintah-kota-palangka-raya/

Putri, D.A., Rahayu, T. 2014. Aktivitas Antibakteri Ekstrak Bawang Putih (Allium sativum) Dan Black Garlic Terhadap Escherichia ColiSensitif Dan Multiresisten Antibiotik. Proceeding Biology Education Conference. 11(1):390-394.

Rahmiyati, N., Andayani, S., Panjaitan, H. 2015. Model Pemberdayaan Masyarakat Melalui Penerapan Teknologi Tepat Guna di Kota Mojokerto. JMM17: Jurnal Ilmu ekonomi dan manajemen. 2(2):48-62. https://doi.org/10.30996/jmm.v2i02.506

Satyaji, H.L. 2018. Analisis Kelayakan dan Usulan Model Bisnis Produksi Bawang Hitam (Black Garlic). Skripsi. Bandung: Universitas Katolik Parahyangan.

Wang, X., Jiao, F., Wang, Q.W., Wang, J., Yang, K., Hu, R.R., Liu, H.C., Wang, H.Y., Wang, Y.S. 2011. Aged black garlic extract induces inhibition of gastric cancer cell growth in vitro and in vivo. Molecular Medicine Reports. 5(1):66-72. https://doi.org/10.3892/mmr.2011.588 